\title{
Balancing Assessment with "In-Service Practical Training": A Case Report on Collaborative Curriculum Design for Delivery in the Practice Setting
}

\author{
Cicely Roche ${ }^{1, *}$, Michelle Flood ${ }^{2}$, , Matthew Lynch $^{2}$ and Laura J. Sahm ${ }^{3,4}$ \\ 1 School of Pharmacy \& Pharmaceutical Sciences, Trinity College, Panoz Building, College Green, \\ Dublin 2, Ireland \\ 2 School of Pharmacy, Royal College of Surgeons, Dublin 2, Ireland \\ 3 Pharmaceutical Care Research Group, School of Pharmacy, University College Cork, Cork T12 YN60, Ireland \\ 4 Department of Pharmacy, Mercy University Hospital, Grenville Place, Cork T12 WE28, Ireland \\ * Correspondence: rocheci@tcd.ie; Tel.: +353-1-896-2827
}

Received: 10 May 2019; Accepted: 11 July 2019; Published: 16 July 2019

\begin{abstract}
Three Higher Education Institutions (HEIs) in Ireland are accredited to provide education and training, successful completion of which, entitles one to register as a pharmacist with the Pharmaceutical Society of Ireland (PSI). Legislation (2014) mandated that these HEIs replace their existing structure (four-year degree followed by a one-year internship), with a five-year 'integrated Master's programme'. Integration includes 'in-service practical training' (placement) at the beginning of Year 4 (four months), and the end of Year 5 (eight months). Year 4 placements do not have to be 'patient-facing'. Students receive a Bachelor's degree at the end of Year 4. The Affiliation for Pharmacy Practice Experiential Learning (APPEL), established by the HEIs, manages student placements, training establishments, preceptor training, the preceptors' competency assessment process, and the virtual learning environment (VLE) that enables delivery of co-developed online modules aligned with placements in Years 4 and 5. This case report aims to describe the process by which this integration has taken place across and within these HEIs and the challenges faced by educators, students, preceptors, and other stakeholders along the way.
\end{abstract}

Keywords: in-service practical training; peer-learning; rubrics; integrated curriculum; co-developed modules; online learning

\section{Background and Introduction}

In Ireland, three Higher Education Institutions (HEIs) - the Royal College of Surgeons in Ireland (RCSI), Trinity College Dublin (TCD), and University College Cork (UCC)—are accredited to provide programmes of 'education and training', graduates of which are entitled to apply to register as a pharmacist [1]. Prior to September 2015, students completed a four-year undergraduate degree, followed by a 12-month period of pre-registration training: The National Pharmacy Internship Programme (NPIP) [2]. A review of undergraduate and pre-registration training, the Pharmacy Education and Accreditation Review (PEARs) project [3] was commissioned by the Pharmaceutical Society of Ireland (PSI) and recommended the introduction of an integrated five-year Master's level programme of education and training for pharmacists. The PSI accepted the PEARs findings and following legislative change in 2014, the five-year integrated programme was introduced in the three HEIs in September 2015 [4]. The PSI's Core Competency Framework (CCF) for Pharmacists [5] was a mandatory component informing the design of the integrated programmes in each HEI. The CCF 
delineates 6 domains of practice, and associated 25 competencies. The CCF informs the PSI's standards for accrediting pharmacy degree programmes $[5,6]$. Curriculum design must therefore map to the CCF. The reference to 'integrated' includes 'in service practical training' (placement) for four months at the beginning of Year 4, and for the final eight months of Year 5 [6]. An overview of the CCF is provided in Table 1.

Table 1. Core Competency Framework (CCF) for Pharmacists.

\begin{tabular}{cl}
\hline \multicolumn{1}{c}{ Domain } & \multicolumn{1}{c}{ Competency } \\
\hline \multirow{3}{*}{ Professional practice } & Practises 'patient-centred' care \\
& Practises professionally \\
& Practises legally \\
& Practises ethically \\
& Engages in appropriate continuing professional development \\
\hline \multirow{3}{*}{ Personal skills } & Leadership skills \\
& Decision making skills \\
& Team working skills \\
& Communication skills \\
\hline \multirow{3}{*}{ Supply of medicines } & Manufactures and compounds medicines \\
& Manages the medicines supply chain \\
& Reviews and dispenses medicines accurately \\
\hline \multirow{3}{*}{ Public health } & Patient consultation skills \\
& Patient counselling skills \\
& Reviews and manages patient medicines \\
& Identifies and manages medication safety issues \\
& Provides medicines information and education \\
\hline & Population health \\
& Health promotion \\
& Research skills \\
\hline \multirow{2}{*}{ Organisation and management skills } & Self-management skills \\
& Workplace management skills \\
& Human resources management skills \\
& Financial management skills \\
& Quality assurance \\
\hline & (PSI, 2013:10) [5]. \\
\hline
\end{tabular}

\section{Aim and Objectives}

The aim of this case report is to detail the process by which HEIs in Ireland collaborated to design a common curriculum, integrated both within and across HEIs, for delivery to students while undertaking placement in Year 4 and to consider the associated challenges faced by educators, students, preceptors, and other stakeholders.

The objectives are to describe this process according to three distinct constituent phases as follows: planning, implementation, and review.

Planning Phase:

(i) To describe the structures necessary to operationalize these new requirements.

(ii) To explain the alignment of student contact hours in the online modules with placement hours.

(iii) To define Preceptors and their scope.

(iv) To outline the criteria for curriculum design.

(v) To define and explain the two stages of the work programme, i.e., Stage 1: Establishment of Working Group (WG) and Stage 2: Curriculum Design.

Implementation Phase:

(i) To designate the outcomes achieved and their linkage to CCF, learning outcomes, assessment, teaching, and learning. 
(ii) To describe the outputs achieved, and to discuss in the context of the literature.

Review Phase:

To describe the challenges, learnings, and recommendations for future iterations

\section{Planning Phase}

\subsection{Structures}

The three HEIs established the Affiliation for Pharmacy Practice Experiential Learning (APPEL) with the Head of each HEI being appointed to its Board of Directors. APPEL is responsible for the management of (a) student placements; (b) training establishments; (c) preceptor-student matching; (d) preceptor training; and (e) the workplace-based competency assessment process [6]. It also manages the virtual learning environment (VLE) that enables delivery of co-developed online modules aligned with placement in Years 4 and 5.

With respect to training establishments, unlike in Year 5 where placements are restricted to hospital or community settings, students in Year 4 also have a range of non-clinical options available for placements-e.g., in a pharmaceutical company, a pharmaceutical wholesaler, or a regulatory body [6]. Additionally, in some circumstances the student may undertake a Year 4 placement outside of the State [7]. As many placement establishments are geographically removed from the HEIs, students would not be able to attend the HEI while on placement, therefore all activities aligned with the online modules, including assessment, needed to be completed at a distance on the APPEL VLE.

As Year 4 placement options do not necessarily facilitate students engaging directly with patients, curriculum design must preclude any activity or assignment that requires student access to patients or patient-records. Accordingly, only three of the six domains in the CCF, namely: professional practice, personal skills, and organisation and management skills (Table 1), are directly aligned with the online modules for Year 4.

\subsection{Alignment of Student Contact Hours}

Degree awards in HEIs in the Republic of Ireland align with the European Credit Transfer and Accumulation System (ECTS). These credits represent the workload and defined learning outcomes in a programme [8]. Sixty ECTS, representing $1500-1800 \mathrm{~h}$ of student effort, are equivalent to a full year of study or work in an undergraduate degree programme [8]. As the Year 4 placement aligns with half the academic year for an undergraduate student, this represents 30 ECTS of placement time and study, and the corresponding student workload in each HEI is set at a maximum of $750 \mathrm{~h}$ (equivalent to $50 \mathrm{~h}$ per week for 15 weeks). The Board of APPEL agreed that students would complete $30 \mathrm{~h}$ per week in their placement, between the hours of 9 a.m. to 5.30 p.m., four days per week, during Monday to Friday. Therefore, curriculum design had to take account that the time remaining after that assigned to placement activities that could be allotted to Year 4 online modules was a maximum of $20 \mathrm{~h}$ per week.

\subsection{Preceptors and Their Scope}

Preceptors are registered pharmacists who agree to mentor and assess students on the skills that they demonstrate. Their role (in Year 4), is to complete the competency assessment of the student and determine whether, upon completion of the placement, the student has achieved a minimum of, a Level 3 ("mostly") rating (Table 2) in all relevant behaviours (51 behaviours) (see Appendix A, Table A1).

While the competency assessment has no marks associated with it per se, it is a compulsory element that must be successfully completed-i.e., attain a Level 3 award in the designated competencies-in order to pass the module. Further discussion on the competency assessment process is outside the scope of this case report. 
Table 2. Assessment Ratings.

\begin{tabular}{ccr}
\hline Level & Rating & Definition \\
\hline N/A & Cannot & Student not exposed to this behaviour in the training establishment. \\
\hline 1 & Rarely & $\begin{array}{c}\text { Very rarely meets the standard expected. } \\
\text { No logical thought process appears to apply. }\end{array}$ \\
\hline 2 & Sometimes & Rarely meets the standard expected. Much more haphazard than "mostly". \\
\hline 3 & Mostly & Standard practice usually met with occasional lapses. \\
\hline 4 & Consistently & Demonstrates the expected standard practice with rare lapses. \\
\hline & & (CoDEG, 2007) ([9] (adapted)).
\end{tabular}

\subsection{Criteria for Curriculum Design}

When designing the curriculum for students completing placements in Year 4 of the programme, it was necessary to take account of a complex series of interrelationships, summarised in Figure 1.

APPEL provided further requirements that further informed the curriculum design as follows:

- Materials should be co-delivered to students from all three HEIs while on Year 4 placement, from September to December of that academic year;

- there should be no requirement for students to attend the HEI at any stage during the placement;

- activities that require access to patients or patients' records should be excluded;

- learning outcomes to be derived from the same CCF behaviours as used for the placement assessment;

- alignment with 30 ECTS academic credit for Year 4 of the Degree award, and with student workload of a maximum $20 \mathrm{~h}$ per week for a total of 15 weeks is a requirement;

- there should be no additional preceptor workload when designing activities/assessment; and

- standards and/or regulations for curriculum design, and for progression and award of Degrees, at all three HEIs were to be accommodated. 
Statutory Requirements [1,5-7]

\begin{tabular}{|c|c|c|c|c|}
\hline \multicolumn{2}{|c|}{$\begin{array}{l}\text { National framework of Qualifications (NFQ) Requirements. } \\
\qquad[8]\end{array}$} & & \multicolumn{2}{|c|}{$\begin{array}{l}\text { Accreditation Standards, the Pharmaceutical Society of Ireland } \\
\text { (PSI). [4] }\end{array}$} \\
\hline $\begin{array}{l}\text { Learning outcomes must align with Core } \\
\text { Competency Framework for Pharmacists } \\
\text { (CCF) (Table 1). }\end{array}$ & \multicolumn{2}{|c|}{$\begin{array}{l}\text { Year 4, four-month placement: } \\
\text { any pharmacy setting is } \\
\text { allowed. }\end{array}$} & $\begin{array}{l}\text { Competency-based } \\
\text { assessment is required in } \\
\text { placement. }\end{array}$ & $\begin{array}{c}\text { Award of academic credit requires } \\
\text { Modular structure, } 3 \times 10 \text { ECTS [8] } \\
\text { online learning and assessment. }\end{array}$ \\
\hline \\
\hline \multicolumn{5}{|c|}{ Module Learning Outcomes (LOS) derive from relevant behaviours in CCF, assessment design aligns with LOs, and content supports achievement of LOs. } \\
\hline \multicolumn{3}{|c|}{$\begin{array}{c}\text { Competency Assessment by preceptors aligns with Learning from } \\
\text { placement (Table 2). }\end{array}$} & \multicolumn{2}{|c|}{$\begin{array}{l}\text { Online Modules' assessment design drives engagement with preceptors and } \\
\text { colleagues in placement (Figure 2). }\end{array}$} \\
\hline
\end{tabular}

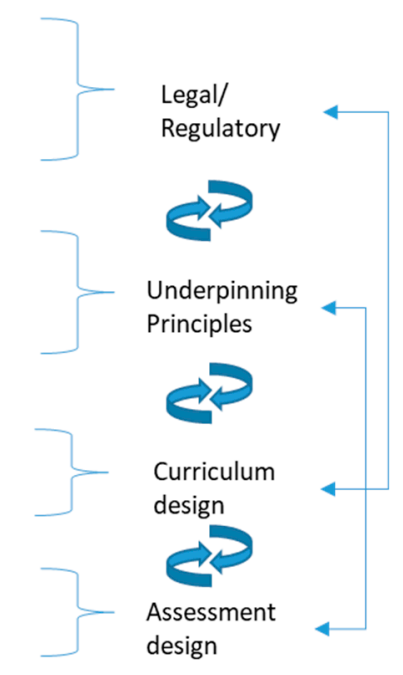

Figure 1. Interrelationships between legal requirements, underpinning principles, and curriculum and assessment design. 


\subsection{Stages of Work Programme}

\section{Stage 1: Establishment of Working Group}

APPEL appointed a working group (WG), composed of one pharmacist nominee from each of the HEIs (CR, MF, and LJS) charged with drafting a proposal by December 2017 for a curriculum design that would be common to all HEIs and which would be co-delivered to students while undertaking practice placements in Year 4. APPEL stipulated that the curriculum design should have a University character, including its expectation that there would be synchronous, online activity on a regular basis-preferably no less than once weekly.

All members of the WG had experience in curriculum design, online learning, and assessment. A Practice educator at RCSI/APPEL, the project manager at APPEL, and the instructional designer at TCD provided support to the WG, and each member of the WG collaborated with colleagues in their respective HEIs, working towards the preparation and delivery of curriculum materials in September-December 2018.

Stage 2: Curriculum Design—Alignment of Learning Outcomes with Activities and Assessment

The WG adopted a student-centred, outcomes-focused approach to curriculum design [8-10] and prioritised integration of content and activities to the assessment design [11-13]. Rubrics were sufficiently detailed to guide both students and assessors [14]. Online modules were designed to be in synergy with the experiential nature of placements-i.e., to support learning by doing while on placement [15-17]. Developmental approaches to reasoning and decision-making through the ambiguity experienced in 'practice' [18-20], as previously used in online and blended learning in Pharmacy education in Ireland [21-23], were a central component of curriculum design.

The WG committed to providing a guided approach to reflective writing $[24,25]$ and, combined with promoting repeated cycles of reflection $[15,16,26]$, this commitment further informed the format, sequencing, and timing of activities and student submissions [27-29]. Individual and social constructivist theories $[15,30]$, which propose that learning is an active process wherein new information is added to 'prior knowledge' which may have been derived from experience as well as formal teaching and learning, and that can take place on an individual or social basis, underpinned curriculum design. Assessment that was simultaneously 'of' (demonstrating achievement), 'for' (to provide feedback by e.g., self and peer assessment against comparators), and 'as' (wherein students self-regulate) learning [31-33] was the aim. Peer interaction and debate [34,35] was stimulated by appropriate sequencing of the order in which students completed activities [20-23]. Selection of team tasks, and Community of Inquiry methodologies which prompted emphasis on social presence (e.g., interacting in teams to agree decisions), cognitive presence (e.g., activities requiring critical and independent thinking), and teaching presence (i.e., the establishment of a defined process to drive reflection and interaction online) [36] further encouraged student engagement $[37,38]$ with their online groups, and with the range of experts (e.g., preceptors) accessible during their placements. Participation in peer review and feedback [39], required for programme accreditation purposes [3], was introduced as a group activity. The WG aimed to maximise the potential arising from an entirely online learning, feedback and assessment environment [40], especially with respect to demonstration of professionalism and online etiquette ("netiquette") when interacting with peers [41].

The WG convened on six occasions for two days meetings, from April to October 2017, and issued progress reports, including recommendations for decision to the Board of APPEL, after each meeting.

An overview of the assessment design, and its alignment with content, activities and the placement, is provided in Figure 2. 


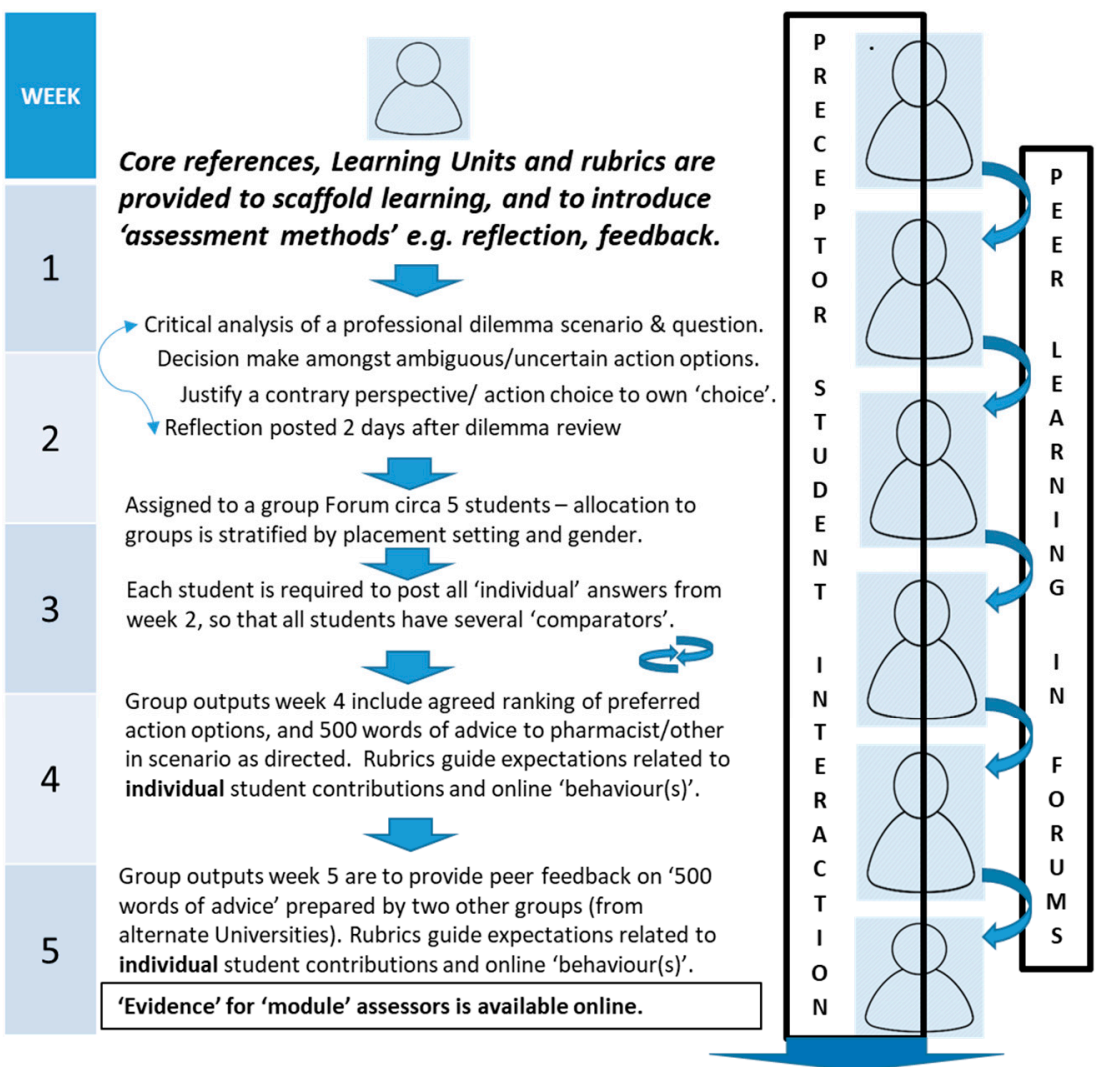

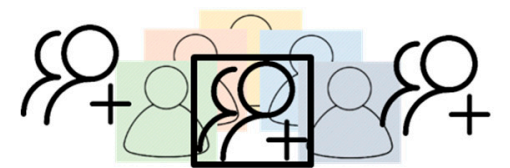

Forums: Peer learning/ community of Inquiry: activity/ies

design prompts synchronous peer interaction on Wednesday.

$$
\text { ए }
$$

Full 'class' Forums from week 1 continue to be available to students to share learning throughout week 2, and throughout the Module. i.e. a self directed approach to continuation of Peer learning/ community of Inquiry activity/ies.

$$
\square
$$

Students share, and compare, individual answers. Differences are explored.$$
\text { ar }
$$

'Team' member activities: • Discuss intragroup perspectives.

Intragroup activities Each student engages Discuss intragroup perspectives. - Access to insight(s) from both ow

- Discuss, peers' preceptors.

of various perspectives and towards group agreement(s).

- Rubrics guide expectations related to bot gride expectations related (decision(s) and 'advice'.

Assessment of Group interactions and process to prepare ‘per feedback che guide expectations related online 'behaviour(s)'. 'Evidence' for 'module' assessors is available online.

Figure 2. Student learning process aligned with online modules and Assessment of, for and as learning. * Assessment of (to demonstrate achievement), for (to provide feedback by e.g., self or peer assessment against comparators) and as learning wherein students self-regulate) [31]. 


\section{Implementation Phase}

The curriculum design for modules for Year 4 were progressed in terms of:

\subsection{Module Links to CCF}

- The WG reviewed behaviours listed in the three Domains in the CCF and recommended that 51 behaviours be included (Appendix A, Table A1).

- Each module was linked to a number of CCF competencies and behaviours relevant to the range of placement types possible in Year 4 (Appendix A, Table A1).

- These behaviours guided the development of LOs for each module.

\subsection{Module Learning Outcomes (LOs)}

- Module learning outcomes were devised based on covering the cognitive (knowledge, comprehension, application, analysis, synthesis), affective, and psychomotor domains relevant to a student in Ireland. [42]

- Eight LOs were agreed for each module, of which three LOs were common across each module-i.e., (i) Participate in accordance with the behaviours in domain [x] of the CCF; (ii) Integrate knowledge and skills to ensure safe and effective practice; and (iii) Demonstrate engagement in reflective practice and continuing professional development.

\subsection{Approaches to Assessment}

- Each module included one case-based assessment, to assist in achieving the LOs, that requires (i) Individual and group work, and (ii) self- and peer assessment (Figure 2).

\subsection{Approaches to Teaching and Learning}

- Student workload was determined to be ten hours per week on structured learning (directed learning (DL)) activities, and $10 \mathrm{~h}$ per week on personal learning (self-directed learning (SDL)) activities.

- $30 \mathrm{~h}$ per week were assigned to placement related activity.

- Reference to DL included provision of nine 20 min interactive vodcasts/Learning Units (LUs) and two 'core references', that collectively supported achievement of the LOs and completion of assignments in each module.

An outline module descriptor for the first module delivered is provided in Appendix A, Table A2.

3.5. Outputs

- Three 10 ECTS Modules, each of which aligned with 200 to $250 \mathrm{~h}$ of student effort, [43] were developed.

- Credits aligned with 10ECTS are divided between individual (50\%) and group activities (50\%). Nine LUs were developed, and weekly synchronous, online activities which include self-directed learning, individual and group activities are aligned with scheduled time online, between 1:00 p.m. and 5:00 p.m. on Wednesday afternoons.

- Case video (Appendix A, Table A3) is used as a vehicle to pose relevant questions and motivate discussion within groups. Two core references, available to students prior to viewing the video, provide background information for the case.

- All student activities/outputs were collated to the group's online discussion Forum i.e., all 'evidence' is available in the one discussion Forum.

- Detailed rubrics, with a total of 10 criteria, provided guidance to students and to assessors. (See Appendix A, Table A4 for individual activities rubric and Appendix A, Table A5 for group activities rubric). 
- A student guidance booklet and a module co-ordinator information booklet were developed.

- Weekly announcements, reminding students of activities and related expectations of them during that week, were prepared.

- A weekly schedule, of student learning and assessment, is provided in Appendix A, Table A6.

The module was delivered to students from all three HEIs on time, and all activities were completed as required. LUs and core references were accessed by all students, averages grades were comparable across the HEIs, and were in line with what would be expected at Year 4 of the Bachelor's Degree. The range of marks awarded to students was acceptably in line with institutional norms.

\section{Review Phase}

Following the implementation phase, a review of the initial iteration of the Year 4 programme was undertaken. Arising from this, various challenges, learnings, and recommendations emerged as follows.

\subsection{Challenges}

The technology raised challenges regarding risks of plagiarism and impersonation. While efforts to manage this risk included the use of detailed rubrics, the expectation that students make multiple contributions to module discussion forums and that rubrics allow the alignment of grades to meaningful contributions in group discussions, there remained some risk of online impersonation and/or plagiarism.

Incorporation of online groups included the need for assurance that activities occur in a timely fashion. Accordingly, the design process must pay particular attention to guidelines that prompt timely engagement by all group members, so that those engaging in the early stages do not become despondent with the online teamwork.

Allocation of $50 \%$ of module marks to the individual component, which restricted students to a 500 words submission, required students to accommodate a significant change in their usual approach to such assignments. This limited word count aligned with the experiential nature of placements, wherein patient notes and recordings of events must be complete yet cogent and concise.

The requirement that students had to be online synchronously on Wednesdays was queried by various parties including preceptors wanting students to engage in other placement activities occurring at that time. However, the realization that one late or non-engaging student can impact on their entire group's performance, combined with the stipulation by APPEL that there be must be regular synchronous online activity, generally overcame this difficulty.

\subsection{Learnings}

Concerns raised by academic colleagues across each HEI, that there would be no summative examination and that group work could lead to grade inflation and/or poor grade differentiation, did not materialise as the mean and distribution of grades across each module were within institutional norms.

Rubrics, collaboratively prepared by the module leads in each HEI, motivated detailed planning regarding grading expectations and supported consistency in approach to subsequent module development-i.e., the rubric format remained constant across modules—and serendipitously much of the rubric descriptors required little amendment for subsequent modules (Appendix A, Tables A4 and A5).

Assessment load for assessors for the first module is estimated at 30 to 40 min per student. This estimation includes two face-to-face meetings involving the module leads from each HEI for the purpose of quality assurance within the module whereby the leads collectively reviewed a sample of individual and group work, prior to grading and discussed the approach to grading. Notwithstanding that streamlining of the administrative elements may reduce time required in future cycles, this time allocation is considered to be acceptable for a 10 ECTS module in Year 4. 
While the use of a shared VLE whose management was outsourced externally required advance agreement across the three HEIs regarding content and process, and restricted the freedom of leads to change material, this ensured a common template and structure for students across each HEI.

\subsection{Recommendations for Future Work}

Staff development should be prioritized in a number of areas including (i) moderating and grading online forums, (ii) development of rubrics, and (iii) development of reflective writing skills in students.

The collaborative approach of the working group should be explored as a potential framework for development of cross-institutional curriculums.

\section{Discussion and Conclusions}

The aim of this case report was to detail the process by which HEIs in Ireland collaborated to design a common curriculum, integrated both within and across HEIs, for delivery to students while undertaking placements in Year 4 and to consider the associated challenges faced by educators, students, preceptors, and other stakeholders.

While the curriculum design process was informed by a number of important interrelationships (Figure 1) and APPEL requirements, the need for it to be student-centered and outcomes-focused [8-10], both from experiential learning perspectives (learning by doing while on placement [15-17]), and with respect to activities and assessment were key determinants. The student view was sought during development, when students attended the face-to-face pre-placement day and during delivery of the first module. The approach was organic in that changes were made as required to take account of particular situations that presented for either individual students or the wider student cohort-e.g., when students requested a later submission time for one assignment to accommodate commuting time from their training establishments. Themes for case scenarios in the three online modules (unlicensed medicines usage, interpersonal relationships and pharmacoeconomic assessment) reflected issues relevant to the profession as a whole, thereby exposing students to a range of dilemmas typically faced in pharmacy practice. As allocation to groups was stratified by training establishment and by gender, groupwork enabled learning from (i) peers in different practice contexts, (ii) collective engagement with a range of preceptors in their role as 'experts', and (iii) interaction with others in the training establishment [15-17] and Figure 2. Constructivism, both individual and social, is the key learning theory used $[15,26,27,31-33]$. A guided approach to reflective writing was provided, using both LUs and the rubric to directly support students' ability to engage with the four levels of written reflection $[24,25]$. By revisiting their own initial response, each student was encouraged to reflect on learning from 'practice'. Group work activity facilitated further expansion of the range of perspectives that could support resolution of the dilemma(s) presented in the relevant scenario.

Integration of learning with the assessment design was achieved by designing activities to act as catalysts for learning from module content and from interaction with the placement, and by setting up and managing the learning environment in a manner that supported students through activities in a specific sequence (Appendix A, Table A6) [11-13]. Student completion of activities provided evidence of 'achievement' that could be objectively assessed. Design of assessment that is ' $o f^{\prime}$, ' $f \circ r^{\prime}$, and ' $a s^{\prime}$ ' learning reduces assessment load for students [31]. Detailed rubrics were provided to students at the beginning of the module thereby clarifying expectations and supporting learning [14]. When assessing student work, each module lead 'benchmarked' submissions against the rubric, thereby enabling student self-assessment prior to engaging in assignments for subsequent modules [39].

Developmental approaches to reasoning and decision-making [18-23]—namely the incorporation of logic or relevant decision-making frameworks, role-play, and peer interaction [18,34,35] —-were a central component of the curriculum design. The LUs added to the knowledge accrued in Years 1-3 of the programme. These also emphasised decision-making frameworks (Appendix A, Table A2), and the requirement that each student, first independently, identify ethical concepts in the dilemma and justify what action should be taken, introduced critical and independent thinking/individual constructivism, 
logic, and role-play to the process (Appendix A, Tables A3 and A6) [35]. Role-play, or the taking account of the perspectives of others, was achieved when students (i) individually completed the ranking of 'less than ideal' action options and (ii) explained how a pharmacist might try to justify the action options that the student chose as least preferred.

Having committed to individual choices regarding rating and ranking of action options offered, students had to agree a group decision regarding the ranking process within a defined time-frame (Figure 2). This inevitably involved negotiation and active discussion, debate and persuasion as the group sought to complete the task by the deadline imposed. The debate also demanded deeper reflection on the student's individual decisions made prior to discussion with their peers. Peer interaction was stimulated by appropriate sequencing of the order in which students completed activities [20-23,34,35]. Group composition was changed for subsequent modules, thereby forcing repeated exposure to 'new' perspectives and approaches to decision-making.

The design enabled and stimulated students to participate as online 'Communities of Inquiry' while collectively sharing the expertise available from preceptors practising in a range of contexts. The requirement to collaboratively prepare 500 words of advice promoted and facilitated student engagement [36-38] with the range of experts (e.g., preceptors) accessible during their placements. The provision of peer feedback on 'advice' prepared by groups from other HEIs required each member to engage with perspectives of their 'own' peers who had studied in different contexts, while also developing the ability to review and feedback on colleagues' work. Students become familiar with the learning and assessment process in this first module and, by repeating the process in subsequent modules, students have opportunity to adapt this 'expertise' so that decision-making through ambiguity becomes tacit, or acquired at a 'bedrock' level [18-23].

The WG used the potential arising from the online learning environment [39] for additional benefit such as to (i) identify whether students had successfully engaged with all online activity 'types' during orientation week and provide struggling students with support prior to the start of the module; (ii) identify that all students completed required individual assignments during the defined timeframe(s), especially during week 2; (iii) provide evidence of, or lack thereof, professionalism in forums; and (iv) accommodate different learner styles by means of incorporating both synchronous and asynchronous interaction [40]. Benchmarking against a detailed rubric enabled feedback from module leads in a timely fashion, while rubric descriptors for higher levels than achieved by students (Appendix A, Tables A4 and A5) provided guidance to students as they self-assessed how they might improve performance in subsequent modules.

As all contributions were recorded online, they collectively provided evidence of the standard to which students had engaged in the process in a format that accommodated individual HEI rules and regulations related to examinations, and decisions related to student progression and awards.

In Section 4, the outcome from the review undertaken after the first iteration of the programme was detailed.

In conclusion, while the overall rollout was successful, it was not without its challenges and there are important learnings that will be taken on board both for future iterations of Year 4 and for the delivery of an analogous education programme for Year 5. Furthermore, they offer valuable insights for those who may be contemplating the development of similar programmes to be delivered in the practice setting in a related educational context.

Author Contributions: All authors contributed to the design and development of the co-delivered modules outlined in this case report, and all authors contributed to and reviewed the manuscript for submission.

Funding: This research received no external funding.

Acknowledgments: The Board of APPEL, who provided guiding principles for the design group and approved the design proposed; Instructional designer Jonathan Walsh; Experts external to the HEIs who supported module coordinators with case development and provided learning units in support of cases for each module; module co-ordinators and practice educators from the three HEIs; The APPEL Project manager Michael Creswell, Practice Educator Ann Teresa Morgan, and wider team who provided technical and other support to all involved in the development and delivery of these modules; and academic and administrative staff in the HEIs who supportive 
adaptation of existing processes and 'rules' to accommodate the use of online processes for learning and assessment in this manner.

Conflicts of Interest: The authors declare no conflict of interest.

\section{Appendix A}

Table A1. CCF Behaviours aligned with Year 4 online modules [5].

\begin{tabular}{|c|}
\hline CCF Behaviours Aligned with Year 4 Online Modules \\
\hline Professional Practice Module \\
\hline 1.1 Practices 'patient-centred' care \\
\hline 1.1.1 Demonstrates a 'patient-centred' approach to practice \\
\hline 1.1.2 Ensures patient safety and quality are at the centre of the pharmacy practice \\
\hline 1.2 Practices professionally \\
\hline $\begin{array}{l}\text { 1.2.2 Demonstrates awareness of the position of trust in which the profession is held and practises in a manner } \\
\text { that upholds that trust }\end{array}$ \\
\hline 1.2.3 Treats others with sensitivity, empathy, respect and dignity \\
\hline 1.2.4 Takes responsibility for their own actions and for patient care \\
\hline $\begin{array}{l}\text { 1.2.7 Recognises their scope of practice and the extent of their current competency and expertise and works } \\
\text { accordingly }\end{array}$ \\
\hline 1.2.8 Maintains a consistently high standard of work \\
\hline 1.3 Practices Legally \\
\hline 1.3.2 Understands and applies the requirements of both Irish and European pharmacy and medicines law \\
\hline $\begin{array}{l}\text { 1.3.3 Demonstrates an awareness of other legislation relevant to their practice setting including as appropriate } \\
\text { data protection law, health and safety law, employment law, consumer law, equality law and intellectual } \\
\text { property rights }\end{array}$ \\
\hline $\begin{array}{l}\text { 1.3.4 Demonstrates an understanding of the requirements of the regulatory framework to authorise a medicinal } \\
\text { product including the quality, safety and efficacy requirements }\end{array}$ \\
\hline 1.4 Practices ethically \\
\hline $\begin{array}{l}\text { 1.4.1 Understands their obligations under the principles of the statutory Code of Conduct for Pharmacists and } \\
\text { acts accordingly }\end{array}$ \\
\hline $\begin{array}{l}\text { 1.4.2 Makes and justifies decisions in a manner that reflects the statutory Code of Conduct for pharmacists and } \\
\text { pharmacy and medicines law }\end{array}$ \\
\hline 1.4.3 Recognises ethical dilemmas in practice scenarios and reasons through dilemmas in a structured manner \\
\hline 1.5 Engages in appropriate continuing professional development (CPD) \\
\hline 1.5.1 Understands and accepts the importance of life-long learning for pharmacists \\
\hline $\begin{array}{l}\text { 1.5.2 Demonstrates the ability to critically reflect on their own practice and skills, to identify learning and } \\
\text { development needs }\end{array}$ \\
\hline $\begin{array}{l}\text { 1.5.3 Takes personal responsibility for engaging in CPD and achieving learning and professional development } \\
\text { goals }\end{array}$ \\
\hline $\begin{array}{l}\text { 1.5.4 Identifies and undertakes appropriate learning activities and programmes that meet identified learning } \\
\text { needs }\end{array}$ \\
\hline Personal Skills Module \\
\hline 2.1 Leadership skills \\
\hline 2.1.1 Inspires confidence and applies assertiveness skills as appropriate \\
\hline 2.1.2 Leads by example by acting to ensure patient safety and quality within the pharmacy environment \\
\hline 2.1.3 Builds credibility and portrays the profession in a positive light by being professional and well informed \\
\hline 2.2 Decision-making skills \\
\hline 2.2.2 Makes decisions and solves problems in a timely manner \\
\hline
\end{tabular}


Table A1. Cont.

\section{CCF Behaviours Aligned with Year 4 Online Modules}

2.2.3 Gathers information from a number of reliable sources and people to enable them to make well-founded decisions

2.2.4 Communicates decisions comprehensively including the rationale behind decisions

2.2.5 Ensures that relevant professional, ethical and patient safety factors are fully considered in decisions into which they have an input

2.2.6 Distinguishes between important and unimportant issues

2.2.7 Demonstrates an attention to detail and accuracy in decision-making

2.2.8 Recognises when it is appropriate to seek advice from experienced colleagues, refer decisions to a higher level of authority or to include other colleagues in the decision

2.3 Team working skills

2.3.1 Recognises the value and structure of the pharmacy team and of a multiprofessional team

2.3.5 Demonstrates a broad understanding of the services delivered by other healthcare professionals and disciplines

2.4 Communication skills

2.4.1 Uses effective verbal, non-verbal, listening and written communication skills to communicate clearly, precisely and appropriately

2.4.3 Uses appropriate language and checks understanding

2.4.4 Demonstrates respect, cultural awareness, sensitivity and empathy when communicating

2.4.5 Demonstrates influencing and negotiation skills to resolve conflicts and problems

Organisation and Management Skills Module

6.1 Self-management skills

6.1.1 Demonstrates organisation and efficiency in carrying out their work

6.1.2 Ensures their work time and processes are appropriately planned and managed

6.1.3 Demonstrates the ability to prioritise work appropriately

6.1.4 Takes responsibility as appropriate in the workplace

6.1.5 Demonstrates awareness of the responsibility of their position

6.1.6 Ensures punctuality and reliability

6.1.7 Reflects on and demonstrates learning from critical incidents

6.2 Workplace management skills

6.2.1 Demonstrates an understanding of the principles of organisation and management

6.2.2 Works effectively with the documented procedures and policies within the workplace

6.2.3 Understands their role in the organisational structure and works effectively within the management structure of the organisation

6.2.5 Addresses and manages day to day management issues as required in their position of responsibility

6.3 Human resources management skills

6.3.3 Engages with systems and procedures for performance management

6.3.4 Supports and contributes to staff training and continuing professional development

6.5 Quality assurance

6.5.1 Recognises quality as a core principle of medicines management and healthcare provision

6.5.2 Understands the role of policies and procedures in the organisational structure and in the provision of healthcare

6.5.3 Contributes to the development, implementation, maintenance and training of staff on standard operating procedures, as appropriate to their level of responsibility

6.5.4 Contributes to regular audit activities and reports and acts upon findings 
Table A2. Module descriptor extracts Professional practice.

\begin{tabular}{|c|c|}
\hline Module Title & Professional Practice (Extracts from Module Descriptor) \\
\hline Credit & 10 ECTS \\
\hline Elective/Mandatory & Mandatory \\
\hline Sequence & Year 4 Placement Module 1 \\
\hline $\begin{array}{l}\text { Indicative Weekly } \\
\text { Schedule }\end{array}$ & $\begin{array}{l}\text { Directed/Structured } \\
\text { - } 15 \mathrm{~h} \text { placement activities } \\
\text { - } \quad 10 \mathrm{~h} \text { online learning Self-Directed/Unstructured } \\
\text { - } \quad 15 \mathrm{~h} \text { placement activities } \\
\text { - } \quad 10 \mathrm{~h} \text { online learning }\end{array}$ \\
\hline Duration & 6 weeks [ 1 week orientation +5 weeks of module] \\
\hline Module Coordinators & $\begin{array}{l}\text { Assoc. Prof. Cicely Roche (TCD) } \\
\text { Dr. Laura Sahm (UCC) } \\
\text { Dr. Matthew Lynch (RCSI) }\end{array}$ \\
\hline Pre-requisites & Completion of year 3 \\
\hline Module Rationale & $\begin{array}{l}\text { This module focuses on CCF Domain 1, Professional Practice and helps students develop } \\
\text { the concept of what it means to be a pharmacist. The module will encompass the legal, } \\
\text { ethical, and professional challenges faced by pharmacists in their working environment. } \\
\text { It will also help raise awareness of the importance and necessity of lifelong learning. }\end{array}$ \\
\hline Module Aim & $\begin{array}{l}\text { This module aims to help students develop their knowledge, skills, and attributes in CCF } \\
\text { Domain 1, Professional Practice. }\end{array}$ \\
\hline Learning Outcomes & $\begin{array}{l}\text { 1. Participate in accordance with the behaviours identified in Domain } 1 \text { of the CCF } \\
\text { 2. Explain the legal requirements regulating the practice of pharmacy } \\
\text { 3. Integrate knowledge and skills to ensure safe and effective practice } \\
\text { 4. Critically review professional dilemma(s) } \\
\text { 5. Rationalise professional decision-making } \\
\text { 6. Illustrate the role of ethical principles in guiding professional behaviour } \\
\text { 7. Justify the value of patient/person-centred practice } \\
\text { 8. Demonstrate engagement in reflective practice and continuing } \\
\text { professional development }\end{array}$ \\
\hline \multirow{3}{*}{ Structure and Content } & $\begin{array}{l}\text { Indicative syllabus/content } \\
\text { Week } 1 \text { : } \\
\text { 1. } \quad \text { Legislation } 1 \\
\text { 2. } \quad \text { Legislation } 2 \\
\text { 3. } \quad \text { Lifelong-learning }\end{array}$ \\
\hline & $\begin{array}{l}\text { Week 2: } \\
\text { 1. Code of conduct } \\
\text { 2. } \quad \text { Approaches to ethical decision-making } \\
\text { 3. } \quad \text { Being an advocate }\end{array}$ \\
\hline & $\begin{array}{l}\text { Week 3: } \\
\text { 1. } \quad \text { Being professional } \\
\text { 2. Industry Perspective on Case } \\
\text { 3. } \quad \text { Regulatory Perspective on Case }\end{array}$ \\
\hline Learning Time & $\begin{array}{l}\text { Each week students will have a combination of learning online and in their placement } \\
\text { setting. } \\
\text { Students will spend } 30 \mathrm{~h} \text { per week learning in their placement, and this will be supported } \\
\text { by } 10 \mathrm{~h} \text { of directed study (online learning activities, completing core and recommended } \\
\text { reading, and completing assessment activities). Students will also be expected to complete } \\
\text { self-directed learning activities of } 10 \mathrm{~h} \text { per week. }\end{array}$ \\
\hline Assessment & $\begin{array}{l}\text { Case-based Online Assessment [100\%] } \\
\text { - Independent work (including critical appraisal and decision-making) [50\%] } \\
\text { - Collaborative group decision making and peer review [50\%] } \\
\text { CA sign-off on Level } 3 \text { in relevant behaviours listed above by the end of the 4-month } \\
\text { placement }\end{array}$ \\
\hline Indicative Reading & See 'full' module descriptor-Includes two core references \\
\hline
\end{tabular}


Table A3. Case study development guidelines (First module delivered 2018).

\begin{tabular}{|c|c|}
\hline $\begin{array}{c}\text { (a) Scenario/case } \\
\text { development }[18,20,21] \text {. }\end{array}$ & $\begin{array}{l}\text { - Develop a scenario that raises various professional/ethical concepts. } \\
\text { In order to create a dilemma, two concepts (at least) are in conflict i.e., an } \\
\text { ethical/professional dilemma involves two or more action options, each of } \\
\text { which is individually convincing, mutually exclusive and jointly } \\
\text { demanding, and none of which is regarded as being fully aligned with all } \\
\text { professional rules, codes, guidelines and ethical concepts. } \\
\text { In order to assure the case study represents one or more dilemma(s), the } \\
\text { case must avoid scenarios where one professional/ethical concept is } \\
\text { 'obviously' dominant. Scenarios may incorporate more than one conflict of } \\
\text { professional/ethical concepts. } \\
\text { The scenario should not permit 'escape' e.g., to the letter of the law or to a } \\
\text { standard clinical decision-making flowchart. } \\
\text { As individual review of the scenario is not meant to be a challenging test } \\
\text { of knowledge, footnotes are included to explain any terms or medicines } \\
\text { relevant to the dilemma. } \\
\text { The scenario/video finishes at a moment in time that can legitimately } \\
\text { require an 'immediate decision in less than ideal circumstances'. }\end{array}$ \\
\hline $\begin{array}{l}\text { (b) Question posed at the } \\
\text { end of the scenario } \\
\text { (September 2018). }\end{array}$ & $\begin{array}{l}\text { - The question aligns with the module LOs and content, and with the rubric } \\
\text { provided to students. } \\
\text { Questions are updated each year and may be prefaced with additional } \\
\text { information related to the case study. }\end{array}$ \\
\hline $\begin{array}{l}\text { (c) Development of } 12 \\
\text { Action options for use in } \\
\text { the first Module }[18,20,21]\end{array}$ & $\begin{array}{l}12 \text { action options are required for each case. In order to facilitate variation } \\
\text { of options in subsequent years, Module coordinators are encouraged to prepare } \\
\text { a minimum of } 18(6 \times 3) \text { when first developing a case. Development of the } 12 \\
\text { options is not intended to be a 'scientific' process, rather that the action options } \\
\text { are approximately equivalent and/or that none is obviously better than the } \\
\text { other three and ordering of the } 12 \text { behaviours in the final 'learning and } \\
\text { assessment' presentation is not random. Options are dispersed throughout (a) } \\
\text { to (l), front loading from the 'personal interest' category, and 'back-loading' } \\
\text { slightly from the 'societal best interests' options. } \\
\text { - Write } 4-6 \text { actions/behaviours that represent [behaviour in the person's } \\
\text { own interest] or [avoidance of taking responsibility] or [not advocating for } \\
\text { an action that should be taken] for the situation (i.e., not defensible from a } \\
\text { professionalism perspective); } \\
\text { Write } 4-6 \text { actions/behaviours that represent behaviour focussed on } \\
\text { maintaining rules/norms/codes e.g., that are articulated by legislature, } \\
\text { policy documents or published professional standards i.e., behaviours that } \\
\text { peers would debate whether 'the behaviour was questionable or } \\
\text { 'defensible' from a professionalism perspective. } \\
\text { Write } 4-6 \text { actions/behaviours that represent behaviour in the patient's } \\
\text { and/or 'society's 'best interests' i.e., behaviour that peers would generally } \\
\text { consider to be Highly Defensible' from a professionalism perspective. }\end{array}$ \\
\hline
\end{tabular}

The components are a professional-specific scenario written as a script for recording of the video, a question posed to students to prompt critical review of the scenario and 12 action options that might be taken immediately after encountering the scenario.

The case aligns with the Module LOs and incorporates material covered in the module. 
(a). Year 4 Professional Practice Module

Box A1. Case study-narration for videoclip.

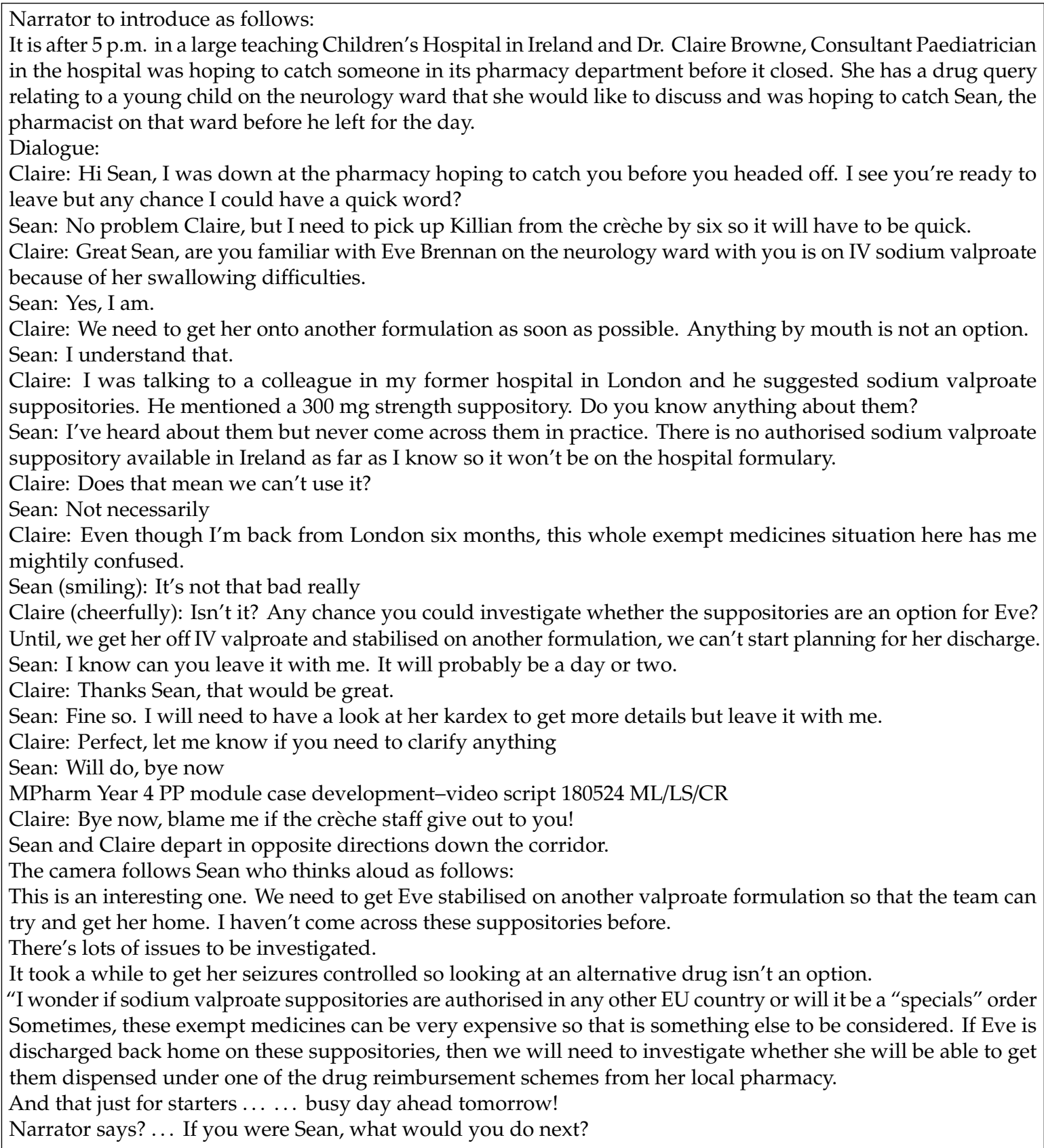

\section{(b) First Module Professional Practice Case Study Video Question Posed}

Identify the main professional and/or ethical concepts, principles in the Code of Conduct and/or relevant legislation that you think might be at risk in this scenario, list what stakeholders you think need to be contacted, and then recommend, with justifications, what the pharmacist should do next i.e., directly after this scenario occurs (wordcount limit 250 words).

(c) Action options that students were required to rate and rank online in 2018 
Rate the importance of each action ((a) to (I) below), in coming to your decision, by circling/ highlighting your rating of 'action' options.

$$
\text { HD = Highly Defensible; } \quad \text { D = Defensible; } \quad Q=\text { Questionable; } \quad \text { ND = Not Defensible }
$$

a. HD D Q ND : Having confirmed the patient's weight and age is appropriate for the dose recommended, order the product.

b. HD D Q ND : Refuse to discuss with Consultant.

c. HD D Q ND : Tell the Consultant that you are aware of the product, have heard mixed reports about its safety/ efficacy and would like to research further before discussing with her any further.

d. HD D Q ND : Have the Consultant sign an application to request this medicine to be added to the Formulary

e. HD D Q ND : Order the product without further consideration of issues involved.

f. HD D Q ND : Go to your chief pharmacist in the hospital and ask him/her to deal with this as you're new to this role.

g. HD D Q ND : Speak directly to the parents to tell them what the Consultant is planning to do.

h. HD D Q ND : If it's on the market in another country its fine for Irish patients.

i. HD D Q ND : You investigate the manufacture of the product to satisfy yourself that it is conducted to an appropriate standard to assure its quality.

j. HD D Q ND : Tell the Consultant that unfortunately as this medicine is not included in the Formulary, you will not be able to order it.

k. HD D Q ND : Having identified other pharmacists with expertise in paediatrics, contact them.

I. HD D Q ND : You confirm that that the product will have the expected therapeutic effect based on its active constituent(s) and its pharmaceutical form.

From the list (a) to (I) above, choose what you consider to be the $\mathbf{3}$ most and 3 least preferred action options.

Pick the 3 most preferred action options:

Pick the 3 least preferred action options:

- Most Preferred Option Least Preferred Option

- Second Most Preferred Option Second Least Preferred Option

- Third Most Preferred Option Third Least Preferred Option

Figure A1. Range of 12 action options, related to the Case scenario (Box A1), provided to students. 
Table A4. Professional practice module (individual work) rubric.

\begin{tabular}{|c|c|c|c|c|c|c|c|}
\hline \multirow{2}{*}{$\begin{array}{c}\text { Year 4: Professional } \\
\text { Practice Module } \\
\text { 190228v2.0 CR/LS/ML } \\
\text { Criteria } \\
\text { (Weighting is } 10 \% \text { per } \\
\text { Criterion) }\end{array}$} & \multicolumn{6}{|c|}{$\begin{array}{c}\text { Rubric for Individual Component: Individual Constructivism, Critical and Integrative Thinking and Reflective Practice are } \\
\text { Emphasised. }\end{array}$} & \multirow{2}{*}{$\begin{array}{c}\begin{array}{c}\text { Total: } 50 \% \text { of } \\
\text { Module MARKS }\end{array} \\
\begin{array}{c}\text { Aligned with } \\
\text { Learning outcome } \\
\text { Numbers }\end{array}\end{array}$} \\
\hline & $\begin{array}{l}\text { Exceptional } \\
\text { Level } 5 \times 5\end{array}$ & Excellent Level $4 \times 5$ & Very Good Level $3 \times 5$ & $\begin{array}{l}\text { Borderline Level } \\
\quad 2 \times 5\end{array}$ & Limited Level $1 \times 5$ & $\begin{array}{l}\text { Unacceptable } \\
\text { Level } 0 \times 5\end{array}$ & \\
\hline $\begin{array}{l}\text { Identifies } \\
\text { Professional/Ethical } \\
\text { concepts in the scenario } \\
\text { and what leads to a } \\
\text { dilemma, and critical } \\
\text { review in a professional } \\
\text { manner. }\end{array}$ & $\begin{array}{l}\text { Answer fulfils } \\
\text { all } \\
\text { requirements } \\
\text { for a level } 4 \\
\text { answer and, in } \\
\text { addition, is } \\
\text { exceptional in } \\
\text { its overall } \\
\text { arguments and } \\
\text { presentation }\end{array}$ & $\begin{array}{l}\text { Comprehensive and } \\
\text { accurate coverage of } \\
\text { the concepts in the } \\
\text { scenario, and the } \\
\text { dilemma itself and } \\
\text { clear linkage with } \\
\text { values in the CoC, } \\
\text { frameworks for } \\
\text { decision-making, } \\
\text { relevant legislation } \\
\text { and issues of consent } \\
\text { and confidentiality as } \\
\text { appropriate. }\end{array}$ & $\begin{array}{l}\text { Accurate and well } \\
\text { informed regarding } \\
\text { concepts in the scenario } \\
\text { and the dilemma itself } \\
\text { and links with CoC or } \\
\text { frameworks for } \\
\text { decision-making with } \\
\text { some omissions or errors. }\end{array}$ & $\begin{array}{l}\text { Generally accurate } \\
\text { with respect to } \\
\text { identification of } \\
\text { concepts with some } \\
\text { omissions or errors. } \\
\text { Poor linkage with } \\
\text { CoC, frameworks for } \\
\text { decision-making or } \\
\text { legislation as } \\
\text { appropriate. Or posts } \\
\text { to group's forum } \\
<24 \text { h 'late' }\end{array}$ & $\begin{array}{l}\text { Does not directly } \\
\text { address the concepts, } \\
\text { the dilemma or link } \\
\text { with CoC, frameworks } \\
\text { for decision-making or } \\
\text { legislation as } \\
\text { appropriate. Or posts } \\
\text { to group's forum } \\
>24 \text { h 'late' }\end{array}$ & $\begin{array}{l}\text { Does not } \\
\text { address the } \\
\text { concepts in the } \\
\text { dilemma. Or } \\
\text { does not } \\
\text { answer the } \\
\text { question(s) } \\
\text { posed. Or does } \\
\text { not post to } \\
\text { group's forum. }\end{array}$ & $1,2,3,4,5,6,7,8$ \\
\hline $\begin{array}{l}\text { Makes and justifies } \\
\text { decisions in a manner that } \\
\text { reflects the statutory Code } \\
\text { of Conduct for } \\
\text { pharmacists and } \\
\text { pharmacy and medicines } \\
\text { law. (CCF) }\end{array}$ & $\begin{array}{l}\text { Answer fulfils } \\
\text { all } \\
\text { requirements } \\
\text { for a level } 4 \\
\text { answer and, in } \\
\text { addition, is } \\
\text { exceptional in } \\
\text { its overall } \\
\text { arguments and } \\
\text { presentation }\end{array}$ & $\begin{array}{l}\text { Answers the question, } \\
\text { offers a critical } \\
\text { analysis of the } \\
\text { scenario and justifies } \\
\text { action choice in an } \\
\text { integrated, logical, } \\
\text { and relevant manner. } \\
\text { Wordcount: 230-270 }\end{array}$ & $\begin{array}{l}\text { Answers the question, } \\
\text { offers some analysis of the } \\
\text { scenario and justifies } \\
\text { action choice in a relevant } \\
\text { manner. Wordcount: } \\
230-270\end{array}$ & $\begin{array}{l}\text { Answers the question } \\
\text { and offers some } \\
\text { analysis of the } \\
\text { scenario without } \\
\text { specifically justifying } \\
\text { the choice made. WC: } \\
<230 \text { or }>270\end{array}$ & $\begin{array}{l}\text { Answers the } \\
\text { question(s), relating } \\
\text { answers to questions } \\
\text { posed, but states own } \\
\text { opinions and choices } \\
\text { rather than seeking to } \\
\text { explain a reasoned } \\
\text { action option. WC: } \\
<200 \text { or }>300\end{array}$ & $\begin{array}{l}\text { No evidence of } \\
\text { trying to } \\
\text { develop a } \\
\text { reasoned } \\
\text { approach to } \\
\text { choosing and } \\
\text { justifying an } \\
\text { action option. }\end{array}$ & $1,2,3,4,5,6,7,8$ \\
\hline $\begin{array}{l}\text { Action choices aligned } \\
\text { with 'expert' view. (i.e., } \\
\text { student rates and ranks } \\
\text { action options provided). }\end{array}$ & $\begin{array}{l}\text { Completes } \\
\text { activity and } \\
\text { posts to } \\
\text { group's forum } \\
\text { by the } \\
\text { deadline(s) } \\
\text { and both top } \\
\text { rank choices } \\
\text { align with } \\
\text { expert view. }\end{array}$ & $\begin{array}{l}\text { This grade is not an } \\
\text { option for this } \\
\text { criterion }\end{array}$ & $\begin{array}{l}\text { Completes activity and } \\
\text { posts to group's forum by } \\
\text { the deadline(s) and one } \\
\text { top rank choice aligns } \\
\text { with expert view. }\end{array}$ & $\begin{array}{l}\text { Completes \& posts to } \\
\text { group's forum within } \\
24 \mathrm{~h} \text { of deadline, and } \\
\text { one top rank choice } \\
\text { aligns with expert } \\
\text { view. }\end{array}$ & $\begin{array}{l}\text { Completes \& posts to } \\
\text { group's forum more } \\
\text { than } 24 \mathrm{~h} \text { after } \\
\text { deadline, and neither } \\
\text { top rank choice aligns } \\
\text { with expert view. }\end{array}$ & $\begin{array}{l}\text { Does not } \\
\text { complete or } \\
\text { does not post } \\
\text { to group's } \\
\text { forum. }\end{array}$ & 4,7 \\
\hline
\end{tabular}


Table A4. Cont.

\begin{tabular}{|c|c|c|c|c|c|c|c|}
\hline \multirow{2}{*}{$\begin{array}{c}\text { Year 4: Professional } \\
\text { Practice Module } \\
\text { 190228v2.0 CR/LS/ML } \\
\text { Criteria } \\
\text { (Weighting is } 10 \% \text { per } \\
\text { Criterion) }\end{array}$} & \multicolumn{6}{|c|}{$\begin{array}{l}\text { Rubric for Individual Component: Individual Constructivism, Critical and Integrative Thinking and Reflective Practice are } \\
\text { Emphasised. }\end{array}$} & \multirow{2}{*}{$\begin{array}{c}\begin{array}{c}\text { Total: } 50 \% \text { of } \\
\text { Module MARKS } \\
\text { Aligned with } \\
\text { Learning outcome } \\
\text { Numbers }\end{array} \\
\end{array}$} \\
\hline & $\begin{array}{l}\text { Exceptional } \\
\text { Level } 5 \times 5\end{array}$ & Excellent Level $4 \times 5$ & Very Good Level 3 × 5 & $\begin{array}{l}\text { Borderline Level } \\
\qquad 2 \times 5\end{array}$ & Limited Level $1 \times 5$ & $\begin{array}{l}\text { Unacceptable } \\
\text { Level } 0 \times 5\end{array}$ & \\
\hline $\begin{array}{l}\text { Take your choice of least } \\
\text { preferred option and } \\
\text { explain how a pharmacist } \\
\text { might justify this choice as } \\
\text { a preferred course of } \\
\text { action. } \\
\text { (100 words) }\end{array}$ & $\begin{array}{l}\text { Answer fulfils } \\
\text { all } \\
\text { requirements } \\
\text { for a level } 4 \\
\text { answer and, in } \\
\text { addition, is } \\
\text { exceptional in } \\
\text { its overall } \\
\text { arguments and } \\
\text { presentation. }\end{array}$ & $\begin{array}{l}\text { Demonstrates } \\
\text { understanding of how } \\
\text { poor professional } \\
\text { decision-making } \\
\text { might arise and how } \\
\text { pharmacists might try } \\
\text { to justify same. } \\
\text { Wordcount: } 90-110 .\end{array}$ & $\begin{array}{l}\text { Demonstrates } \\
\text { understanding of how } \\
\text { poor professional } \\
\text { decision-making might } \\
\text { arise or how pharmacists } \\
\text { might try to justify same. } \\
\text { Wordcount: } 90-110 .\end{array}$ & $\begin{array}{l}\text { States examples of } \\
\text { alternate decisions } \\
\text { that might be taken } \\
\text { without specifying } \\
\text { how pharmacists } \\
\text { might try to justify } \\
\text { same. Or posts to } \\
\text { group's forum }<24 \mathrm{~h} \\
\text { 'late'. WC: }<90 \text { or }>110\end{array}$ & $\begin{array}{l}\text { Gives one example of } \\
\text { an alternate decision } \\
\text { that might be taken } \\
\text { but does not clarify } \\
\text { how a pharmacist } \\
\text { might try to justify } \\
\text { same. Or posts to } \\
\text { group's forum }>24 \mathrm{~h} \\
\text { 'late'. WC: }<80 \text { or }>120\end{array}$ & $\begin{array}{l}\text { Examples of } \\
\text { alternate } \\
\text { actions } \\
\text { /justifications } \\
\text { are not } \\
\text { plausible in the } \\
\text { context of } \\
\text { pharmacy } \\
\text { practice. Or } \\
\text { does not post } \\
\text { to group's } \\
\text { Forum. }\end{array}$ & $2,5,6$ \\
\hline $\begin{array}{l}\text { Reflects on own initial } \\
\text { response to the scenario in } \\
\text { the context of the } 12 \\
\text { action options provided } \\
\text { plus general reflection in } \\
\text { the intervening two days. } \\
\text { Refer to Learning Unit } 3 \text {, } \\
\text { Lifelong Learning. } 150 \\
\text { words }\end{array}$ & $\begin{array}{l}\text { Answer fulfils } \\
\text { all } \\
\text { requirements } \\
\text { for a level } 4 \\
\text { answer and, in } \\
\text { addition, is } \\
\text { exceptional in } \\
\text { its overall } \\
\text { arguments and } \\
\text { presentation }\end{array}$ & $\begin{array}{l}\text { Critical reflection: } \\
\text { This form of reflection } \\
\text { shows, in addition to } \\
\text { dialogic reflection, } \\
\text { evidence that the } \\
\text { learner is aware that } \\
\text { the same actions and } \\
\text { events may be seen in } \\
\text { different contexts, and } \\
\text { that the different } \\
\text { contexts may be } \\
\text { associated with } \\
\text { different explanations. } \\
\text { Wordcount: 135-165 }\end{array}$ & $\begin{array}{l}\text { Dialogic reflection: This } \\
\text { writing suggests that there } \\
\text { is a 'stepping back' from } \\
\text { the events and actions } \\
\text { which leads to a different } \\
\text { level of discourse. There } \\
\text { is a sense of discourse } \\
\text { with the 'self' and an } \\
\text { exploration of the role of } \\
\text { the 'self' in events and } \\
\text { actions. The quality of } \\
\text { judgements and of } \\
\text { possible alternatives for } \\
\text { explaining and } \\
\text { hypothesising are also } \\
\text { considered. The reflection } \\
\text { is analytical or integrative, } \\
\text { linking factors and } \\
\text { perspectives. Wordcount: } \\
\text { 135-165 }\end{array}$ & $\begin{array}{l}\text { Descriptive reflection: } \\
\text { This is a description of } \\
\text { events, that also shows } \\
\text { some evidence of } \\
\text { deeper consideration } \\
\ldots \text { but in relatively } \\
\text { descriptive language. } \\
\text { There is no real } \\
\text { evidence of the notion } \\
\text { of alternative } \\
\text { viewpoints in use. Or } \\
\text { posts to group's forum } \\
<24 \mathrm{~h} \text { 'late'. WC: }<135 \\
\text { or }>165\end{array}$ & $\begin{array}{l}\text { Descriptive writing: } \\
\text { This is a description of } \\
\text { events .... It does not } \\
\text { show evidence of } \\
\text { reflection. Note: Some } \\
\text { parts of a reflective } \\
\text { account will need to } \\
\text { describe the } \\
\text { context--but in the } \\
\text { case of 'descriptive } \\
\text { writing', the writing } \\
\text { does not go beyond } \\
\text { description. Or posts } \\
\text { to group's forum } \\
>24 \text { h 'late' WC: }<120 \\
\text { or }>180\end{array}$ & $\begin{array}{l}\text { Does not } \\
\text { complete the } \\
\text { reflection. Or } \\
\text { does not post } \\
\text { to group's } \\
\text { forum. }\end{array}$ & $1,3,8$ \\
\hline
\end{tabular}


Table A5. Professional practice module (group work) rubric.

\begin{tabular}{|c|c|c|c|c|c|c|c|}
\hline \multirow{2}{*}{$\begin{array}{l}\text { Year 4, Professional } \\
\text { Practice Module } \\
\text { 190229v2.0 CR/LS/ML } \\
\text { Criteria (Weighting is } \\
10 \% \text { per criterion) }\end{array}$} & \multicolumn{6}{|c|}{$\begin{array}{c}\text { Rubric for Group/Teamwork Component (accounts for 50\% of marks); Emphasis on Social Constructivism, Professionalism, and Peer } \\
\text { Review }\end{array}$} & \multirow{2}{*}{$\begin{array}{c}\begin{array}{c}\text { Total } 50 \% \text { of } \\
\text { Module Marks }\end{array} \\
\begin{array}{c}\text { Aligned with } \\
\text { Learning Outcomes }\end{array}\end{array}$} \\
\hline & $\begin{array}{l}\text { Exceptional Level } \\
\qquad 5 \times 5\end{array}$ & Excellent Level $4 \times 5$ & $\begin{array}{l}\text { Very Good Level } \\
\quad 3 \times 5\end{array}$ & $\begin{array}{l}\text { Borderline Level } \\
\quad 2 \times 5\end{array}$ & Limited Level $1 \times 5$ & $\begin{array}{l}\text { Unacceptable } \\
\text { Level } 0 \times 5\end{array}$ & \\
\hline $\begin{array}{l}\text { Strategy to address the } \\
\text { scenario posted to } \\
\text { include: Content, } \\
\text { appropriateness of } \\
\text { advice, structure and } \\
\text { referencing, Note 1: } \\
\text { Referencing is to be } \\
\text { Vancouver style. } \\
\text { References are not } \\
\text { included in } \\
\text { 'wordcount' } \\
\text { calculation. Note 2: } \\
\text { For this criterion, the } \\
\text { same mark will be } \\
\text { awarded to all group } \\
\text { members. }\end{array}$ & $\begin{array}{l}\text { Answer fulfils all } \\
\text { requirements for a } \\
\text { level } 4 \text { answer and, } \\
\text { in addition, is } \\
\text { exceptional in its } \\
\text { overall arguments } \\
\text { and presentation. }\end{array}$ & $\begin{array}{l}\text { Comprehensive, } \\
\text { accurate, and } \\
\text { well-informed overage } \\
\text { of the concepts in the } \\
\text { scenario/dilemma. } \\
\text { The group provides } \\
\text { cogent, well-reasoned } \\
\text { 'advice', derived from } \\
\text { the evidence base, to } \\
\text { the pharmacist. } \\
\text { References are of a } \\
\text { high standard and are } \\
\text { well integrated with } \\
\text { the advice (Vancouver } \\
\text { style). Wordcount } \\
\text { (WC): } 450-550 \text { words }\end{array}$ & $\begin{array}{l}\text { Accurate and well } \\
\text { informed regarding } \\
\text { concepts in the } \\
\text { dilemma. The group } \\
\text { posts appropriate } \\
\text { 'advice' to the } \\
\text { pharmacist References } \\
\text { are of a high standard } \\
\text { but not integrated } \\
\text { with the argument } \\
\text { (Vancouver style). } \\
\text { WC: } 450-550\end{array}$ & $\begin{array}{l}\text { Occasional omission } \\
\text { of key factors that } \\
\text { should be addressed } \\
\text { in response to the } \\
\text { scenario presented. } \\
\text { Advice provided } \\
\text { meets minimal } \\
\text { standard. } \\
\text { References are } \\
\text { provided, but are of } \\
\text { a minimal standard. } \\
\text { Advice posted after } \\
\text { the deadline, but } \\
\text { within the same day. } \\
\text { WC: }<450 \text { or }>550\end{array}$ & $\begin{array}{l}\text { Omission of many of } \\
\text { the key factors that } \\
\text { should be addressed } \\
\text { in response to the } \\
\text { scenario presented. } \\
\text { Or advice provided } \\
\text { is not of minimal } \\
\text { standard. Or } \\
\text { referencing is absent } \\
\text { or of a very poor } \\
\text { standard. Or advice } \\
\text { is posted after the } \\
\text { due date, but up to } \\
24 \mathrm{~h} \text { after due date. } \\
\text { WC: }<400 \text { or }>600\end{array}$ & $\begin{array}{l}\text { Advice has not } \\
\text { been posted within } \\
24 \mathrm{~h} \text { after due date. } \\
\text { Or advice failed to } \\
\text { fulfil any of the } \\
\text { module learning } \\
\text { outcomes. }\end{array}$ & $1,2,3,7,8$ \\
\hline $\begin{array}{l}\text { Demonstrates } \\
\text { professionalism and } \\
\text { observes netiquette } \\
\text { when preparing } 500 \\
\text { words of advice, and } \\
\text { when ranking action } \\
\text { options as a group. }\end{array}$ & $\begin{array}{l}\text { Answer fulfils all } \\
\text { requirements for a } \\
\text { level } 4 \text { answer and, } \\
\text { in addition, is } \\
\text { exceptional in its } \\
\text { overall arguments } \\
\text { and presentation. }\end{array}$ & $\begin{array}{l}\text { The group at all times } \\
\text { engaged in the } \\
\text { consideration of the } \\
\text { scenario in a highly } \\
\text { professional, } \\
\text { patient-focused, and } \\
\text { dignified manner. }\end{array}$ & $\begin{array}{l}\text { The group generally } \\
\text { engaged in the } \\
\text { consideration of the } \\
\text { scenario in a mostly } \\
\text { professional, } \\
\text { patient-focused, and } \\
\text { dignified manner. }\end{array}$ & $\begin{array}{l}\text { The group } \\
\text { intermittently } \\
\text { engaged in the } \\
\text { consideration of the } \\
\text { scenario in a } \\
\text { professional, } \\
\text { patient-focused, and } \\
\text { dignified manner. }\end{array}$ & $\begin{array}{l}\text { Significant breach of } \\
\text { netiquette on an } \\
\text { individual or } \\
\text { collective basis } \\
\text { which is recognised, } \\
\text { but not satisfactorily } \\
\text { addressed within the } \\
\text { group discussion. }\end{array}$ & $\begin{array}{l}\text { Significant breach } \\
\text { of netiquette on an } \\
\text { individual or } \\
\text { collective basis } \\
\text { which does not } \\
\text { appear to have } \\
\text { been recognised. } \\
\text { Or not submitted. }\end{array}$ & $1,2,3,8$ \\
\hline
\end{tabular}


Table A5. Cont.

\begin{tabular}{|c|c|c|c|c|c|c|c|}
\hline \multirow{2}{*}{$\begin{array}{c}\text { Year 4, Professional } \\
\text { Practice Module } \\
\text { 190229v2.0 CR/LS/ML } \\
\text { Criteria (Weighting is } \\
10 \% \text { per criterion) }\end{array}$} & \multicolumn{6}{|c|}{$\begin{array}{l}\text { Rubric for Group/Teamwork Component (accounts for 50\% of marks); Emphasis on Social Constructivism, Professionalism, and Peer } \\
\text { Review }\end{array}$} & \multirow{2}{*}{$\begin{array}{c}\begin{array}{c}\text { Total } 50 \% \text { of } \\
\text { Module Marks }\end{array} \\
\begin{array}{c}\text { Aligned with } \\
\text { Learning Outcomes }\end{array}\end{array}$} \\
\hline & $\begin{array}{l}\text { Exceptional Level } \\
\qquad 5 \times 5\end{array}$ & Excellent Level $4 \times 5$ & $\begin{array}{l}\text { Very Good Level } \\
\quad 3 \times 5\end{array}$ & $\begin{array}{l}\text { Borderline Level } \\
\quad 2 \times 5\end{array}$ & Limited Level $1 \times 5$ & $\begin{array}{l}\text { Unacceptable } \\
\text { Level } 0 \times 5\end{array}$ & \\
\hline $\begin{array}{l}\text { Achieves reasoned } \\
\text { consensus regarding } \\
\text { most and least } \\
\text { preferred action } \\
\text { options in order of } \\
\text { preference, using a } \\
\text { clearly defined } \\
\text { process. }\end{array}$ & $\begin{array}{l}\text { Answer fulfils all } \\
\text { requirements for a } \\
\text { level } 4 \text { answer and, } \\
\text { in addition, is } \\
\text { exceptional in its } \\
\text { overall arguments } \\
\text { and presentation. }\end{array}$ & $\begin{array}{l}\text { Achieves reasoned } \\
\text { consensus regarding } \\
\text { most and least } \\
\text { preferred actions ( } 3 \text { of } \\
\text { each), using a clearly } \\
\text { defined process. }\end{array}$ & $\begin{array}{l}\text { Achieves reasoned } \\
\text { consensus regarding } \\
\text { most and least } \\
\text { preferred actions ( } 3 \text { of } \\
\text { each) with tendency to } \\
\text { use 'voting' to reach } \\
\text { decision(s) (as } \\
\text { opposed to using } \\
\text { voting to inform } \\
\text { decision-making } \\
\text { process. }\end{array}$ & $\begin{array}{l}\text { Achieves reasoned } \\
\text { consensus regarding } \\
\text { most and least } \\
\text { preferred actions ( } 3 \\
\text { of each) without } \\
\text { clearly identifying } \\
\text { ranking. }\end{array}$ & $\begin{array}{l}\text { Achieves consensus } \\
\text { regarding most and } \\
\text { least preferred } \\
\text { action options in } \\
\text { order of preference. } \\
\text { Any individual } \\
\text { student } \\
\text { contributions are } \\
\text { minimal and are } \\
\text { independent of } \\
\text { group discussion } \\
\text { and do not } \\
\text { demonstrate } \\
\text { reflective listening. }\end{array}$ & $\begin{array}{l}\text { Group does not } \\
\text { post all } 6 \text { choices } \\
\text { by the due date } \\
\text { Any individual } \\
\text { student failing to } \\
\text { make } 3 \\
\text { contributions to } \\
\text { the discussion, to } \\
\text { the minimum } \\
\text { standard required. }\end{array}$ & $1,3,4,6,7,8$ \\
\hline $\begin{array}{l}\text { Group undertakes and } \\
\text { agrees Peer Review A } \\
\text { in a manner that } \\
\text { demonstrates } \\
\text { professionalism and } \\
\text { observes netiquette } \\
\text { Note that: Learning } \\
\text { Unit } 7, \text { 'Being } \\
\text { Professional', includes } \\
\text { guidance on peer } \\
\text { review. This peer } \\
\text { review activity should } \\
\text { reflect expectations } \\
\text { outlined in Criterion } 1 \\
\text { of this rubric. }\end{array}$ & $\begin{array}{l}\text { Answer fulfils all } \\
\text { requirements for a } \\
\text { level } 4 \text { answer and, } \\
\text { in addition, is } \\
\text { exceptional in its } \\
\text { overall arguments } \\
\text { and presentation. }\end{array}$ & $\begin{array}{l}\text { Provides a specific, } \\
\text { targeted, realistic, } \\
\text { implementable } \\
\text { sentence of } \\
\text { 'reinforcing' feedback. } \\
\text { Provides a specific, } \\
\text { targeted, realistic, } \\
\text { implementable } \\
\text { sentence of 'how } \\
\text { advice might be } \\
\text { improved'. The group } \\
\text { at all times engaged in } \\
\text { the peer review } \\
\text { process in a highly } \\
\text { professional, } \\
\text { patient-focused, and } \\
\text { dignified manner. }\end{array}$ & $\begin{array}{l}\text { Provides an } \\
\text { appropriate sentence } \\
\text { of 'reinforcing' } \\
\text { feedback. Provides an } \\
\text { appropriate sentence } \\
\text { of 'how advice might } \\
\text { be improved'. The } \\
\text { group generally } \\
\text { engaged in the peer } \\
\text { review process in a } \\
\text { mostly professional, } \\
\text { patient focused and } \\
\text { dignified manner. }\end{array}$ & $\begin{array}{l}\text { Provides a specific, } \\
\text { but } \\
\text { non-implementable } \\
\text { sentence of } \\
\text { 'reinforcing' } \\
\text { feedback. Or } \\
\text { provides a } \\
\text { non-specific } \\
\text { sentence of 'how } \\
\text { advice might be } \\
\text { improved'. The } \\
\text { group intermittently } \\
\text { engaged in the peer } \\
\text { review process in a } \\
\text { professional, } \\
\text { patient-focused, and } \\
\text { dignified manner. }\end{array}$ & $\begin{array}{l}\text { Provides feedback } \\
\text { that is not specific, is } \\
\text { unrealistic and is } \\
\text { non-implementable. } \\
\text { Or significant breach } \\
\text { of netiquette on an } \\
\text { individual or } \\
\text { collective basis } \\
\text { which is recognised, } \\
\text { but not satisfactorily } \\
\text { addressed within the } \\
\text { group discussion. }\end{array}$ & $\begin{array}{l}\text { Doesn't provide } \\
\text { feedback. Or } \\
\text { significant breach } \\
\text { of netiquette on an } \\
\text { individual or } \\
\text { collective basis } \\
\text { which does not } \\
\text { appear to have } \\
\text { been recognised. }\end{array}$ & $1,3,4,5,8$ \\
\hline
\end{tabular}


Table A5. Cont.

\begin{tabular}{|c|c|c|c|c|c|c|c|}
\hline $\begin{array}{l}\text { Year 4, Professional } \\
\text { Practice Module } \\
\text { 190229v2.0 CR/LS/ML }\end{array}$ & Rubric for Group/7 & eamwork Component ( & ccounts for $50 \%$ of mark & $\begin{array}{l}\text { ); Emphasis on Social } \\
w\end{array}$ & Constructivism, Profes & ionalism, and Peer & $\begin{array}{c}\text { Total } 50 \% \text { of } \\
\text { Module Marks }\end{array}$ \\
\hline $\begin{array}{l}\text { Criteria (Weighting is } \\
10 \% \text { per criterion) }\end{array}$ & $\begin{array}{l}\text { Exceptional Level } \\
\qquad 5 \times 5\end{array}$ & Excellent Level $4 \times 5$ & $\begin{array}{l}\text { Very Good Level } \\
\qquad 3 \times 5\end{array}$ & $\begin{array}{l}\text { Borderline Level } \\
\qquad 2 \times 5\end{array}$ & Limited Level $1 \times 5$ & $\begin{array}{c}\text { Unacceptable } \\
\text { Level } 0 \times 5\end{array}$ & $\begin{array}{c}\text { Aligned with } \\
\text { Learning Outcomes }\end{array}$ \\
\hline $\begin{array}{l}\text { Group undertakes and } \\
\text { agrees Peer Review B } \\
\text { in a manner that } \\
\text { demonstrates } \\
\text { professionalism and } \\
\text { observes netiquette. } \\
\text { Note that: Learning } \\
\text { Unit } 7, \text { 'Being } \\
\text { Professional', includes } \\
\text { guidance on peer } \\
\text { review. This peer } \\
\text { review activity should } \\
\text { reflect expectations } \\
\text { outlined in Criterion } 1 \\
\text { of this rubric. }\end{array}$ & $\begin{array}{l}\text { Answer fulfils all } \\
\text { requirements for a } \\
\text { level } 4 \text { answer and, } \\
\text { in addition, is } \\
\text { exceptional in its } \\
\text { overall arguments } \\
\text { and presentation. }\end{array}$ & $\begin{array}{l}\text { Provides a specific, } \\
\text { targeted, realistic, } \\
\text { implementable } \\
\text { sentence of } \\
\text { 'reinforcing' feedback. } \\
\text { Provides a specific, } \\
\text { targeted, realistic, } \\
\text { implementable } \\
\text { sentence of 'how } \\
\text { advice might be } \\
\text { improved'. The group } \\
\text { at all times engaged in } \\
\text { the peer review } \\
\text { process in a highly } \\
\text { professional, } \\
\text { patient-focused, and } \\
\text { dignified manner. }\end{array}$ & $\begin{array}{l}\text { Provides an } \\
\text { appropriate sentence } \\
\text { of 'reinforcing' } \\
\text { feedback. Provides an } \\
\text { appropriate sentence } \\
\text { of 'how advice might } \\
\text { be improved'. The } \\
\text { group generally } \\
\text { engaged in the peer } \\
\text { review process in a } \\
\text { mostly professional, } \\
\text { patient focused, and } \\
\text { dignified manner. }\end{array}$ & $\begin{array}{l}\text { Provides a specific, } \\
\text { but } \\
\text { non-implementable } \\
\text { sentence of } \\
\text { 'reinforcing' } \\
\text { feedback. Or } \\
\text { provides a } \\
\text { non-specific } \\
\text { sentence of 'how } \\
\text { advice might be } \\
\text { improved'. The } \\
\text { group intermittently } \\
\text { engaged in the peer } \\
\text { review process in a } \\
\text { professional, } \\
\text { patient-focused, and } \\
\text { dignified manner. }\end{array}$ & $\begin{array}{l}\text { Provides feedback } \\
\text { that is not specific, is } \\
\text { unrealistic and is } \\
\text { non-implementable. } \\
\text { Or significant breach } \\
\text { of netiquette on an } \\
\text { individual or } \\
\text { collective basis } \\
\text { which is recognised, } \\
\text { but not satisfactorily } \\
\text { addressed within the } \\
\text { group discussion. }\end{array}$ & $\begin{array}{l}\text { Doesn't provide } \\
\text { feedback. Or } \\
\text { significant breach } \\
\text { of netiquette on an } \\
\text { individual or } \\
\text { collective basis } \\
\text { which does not } \\
\text { appear to have } \\
\text { been recognised. }\end{array}$ & $1,3,4,5,8$ \\
\hline
\end{tabular}


Table A6. Summary of student learning and assessment activities (first module).

\begin{tabular}{|c|c|}
\hline Week & Learning and assessment activity/-ies \\
\hline OW & $\begin{array}{l}\text { Student access to all VLE functionality required for activities and assessment are confirmed } \\
\text { during OW including: } \\
\text { - } \quad \text { System of weekly announcements is introduced. } \\
\text { - } \quad \text { MC discussion Forum introduced and clarifies that the MC will respond to queries at } \\
\text { least twice weekly. } \\
\text { - Three LUs introduce students to various aspects of placement learning. } \\
\text { - A video demonstration of activities/submissions completion on the VLE. } \\
\text { - Concept of core references is introduced (online module student guidance booklet } \\
\text { - } \quad \text { Video APPEL handbook). } \\
\text { - Wednesday afternont dilemma' is available for download at } 1 \text { p.m. on } \\
\text { - Student rates and ranks } 12 \text { action options related to the video. } \\
\text { Peer learning by means of contributing responses to prompt questions and } \\
\text { commenting on peer contributions on four Discussion Forums aligned with } \\
\text { core references. }\end{array}$ \\
\hline Moduleweek 1 & $\begin{array}{l}\text { - } \quad \text { Online activities in week } 1 \text { are formative-i.e., no academic credit is awarded. } \\
\text { - Two core references are available to students online. } \\
\text { - Three LUs are released to students. } \\
\text { - } \quad \begin{array}{l}\text { Peer learning is initiated-i.e., students respond to prompt questions and comment } \\
\text { on peer contributions on Forums aligned with core references. }\end{array}\end{array}$ \\
\hline Moduleweek 2 & $\begin{array}{l}\text { - Three LUs are released to students. } \\
\text { - Wednesday 1:00 p.m.: Students are presented with a video encompassing a } \\
\text { professional dilemma, and a question to consider - and must prepare and submit } \\
\text { online a response of } 250 \text { words. } \\
\text { - Once } 250 \text {-word response has been submitted, the } 12 \text { 'Action options' are provided } \\
\text { and students submit individual rating and ranking online. } \\
\text { - Students consider their choice of least preferred option and prepare and submit a (100 } \\
\text { word) explanation of how a pharmacist might justify this choice as a preferred course } \\
\text { of action. } \\
\text { By Friday 9:00 p.m.: Students reflect on their own initial response to the scenario in } \\
\text { the context of the } 12 \text { action options plus general reflection in the intervening two days } \\
\text { to prepare and submit a reflection (150 words). }\end{array}$ \\
\hline Module week 3 & $\begin{array}{l}\text { - The final three LUs for the module are released to students. } \\
\text { - Group allocations are visible to students i.e., they can 'see' names of 'their own' } \\
\text { group members. } \\
\text { By Monday night, each group member posts his/her four individual assignments to } \\
\text { the group's forum i.e., } 250 \text { word answer to the scenario, choices related to ranking of } \\
\text { action options, } 100 \text { word explanation of the reasoning a pharmacist might use to } \\
\text { justify the action option the student listed as the least preferred option, and the } 150 \\
\text { word individual 'reflection'. } \\
\text { - Groups have until Wednesday of week } 4 \text { to complete discussions. }\end{array}$ \\
\hline Module week 4 & $\begin{array}{l}\text { - Groups must agree ranking of three most and least preferred action options, and } \\
\text { prepare } 500 \text { words of advice to the pharmacist, intern, patient, other stakeholder in } \\
\text { the case study and post both as final contribution to the group's forum by 5:00 p.m. } \\
\text { on Wednesday week } 4 \text {. }\end{array}$ \\
\hline Module week 5 & $\begin{array}{l}\text { - Groups are provided with } 500 \text { words of advice written by two other groups. } \\
\text { - Groups must agree two sentences of feedback for each advice one sentence 'to put } \\
\text { things right, and the other reinforcing what is 'good' [39]. } \\
\text { - Group tasks must be submitted as the last post on the relevant forum by 5:00 p.m. on } \\
\text { Wednesday week 5. }\end{array}$ \\
\hline
\end{tabular}




\section{References}

1. Pharmacy Act. 2007. Available online: http://www.oireachtas.ie/documents/bills28/acts/2007/a2007.pdf (accessed on 20 April 2019).

2. Pharmaceutical Society of Ireland (PSI). Interim Accreditation Standards for the Level 9 Master's Degree Awarded on the Successful Completion of The National Pharmacy Internship Programme. 2010. Available online: https://www.thepsi.ie/Libraries/Consultations/Interim_Accreditation_Standards.sflb.ashx (accessed on 24 April 2019).

3. Wilson, K.; Langley, C. Pharmacy Education and Accreditation Reviews (PEARs) Project. Report Commissioned by the Pharmaceutical Society of Ireland. 2010. Available online: https://www.thepsi. ie/Libraries/Education/PEARs_Project_Report.sflb.ashx (accessed on 20 April 2019).

4. Pharmaceutical Society of Ireland (PSI). Accreditation Standards for the Five-Year Fully Integrated Master's Degree Programmes in Pharmacy. 2014. Available online: https://www.thepsi.ie/Libraries/Education/5Yr_ Prog_Accreditation_Standards_FINALApproved_03102014.sflb.ashx (accessed on 21 April 2019).

5. Pharmaceutical Society of Ireland (PSI). Core Competency Framework for Pharmacists. Available online: https://www.thepsi.ie/gns/Pharmacy_Practice/core-competency-framework.aspx (accessed on 21 April 2019).

6. Pharmaceutical Society of Ireland (Education and Training) (Integrated Course) Rules 2014 [S.I. No. 377 of 2014]. Available online: https://www.thepsi.ie/Libraries/Legislation/SI_2014_0377_PSI_Education_and_ Training_Integrated_Course_Rules_2014.sflb.ashx (accessed on 21 April 2019).

7. Pharmaceutical Society of Ireland (Education and Training) (Integrated Course) Rules 2017 [S.I. No. 97 of 2017]. Available online: http://www.irishstatutebook.ie/eli/2017/si/97/made/en/pdf (accessed on 21 April 2019).

8. European Commission (European Credit Transfer and Accumulation System (ECTS)). Available online: https://ec.europa.eu/education/resources-and-tools/european-credit-transfer-and-accumulationsystem-ects_en (accessed on 22 April 2019).

9. General Level Framework, a Framework for Pharmacist Development in General Pharmacy Practice, 2nd ed.; Competency Development and Evaluation Group (CoDEG): London, UK, 2007; Available online: http: //www.codeg.org/fileadmin/codeg/pdf/glf/GLF_October_2007_Edition.pdf (accessed on 7 May 2019).

10. Hussey, T.; Smith, P. The uses of learning outcomes. Teach. High. Educ. 2003, 13, 107-115. [CrossRef]

11. Treleaven, L.; Voola, R. Integrating the development of graduate attributes through constructive alignment. J. Mark. Educ. 2009, 30, 160-173. [CrossRef]

12. Biggs, J. Constructing learning by aligning teaching: Constructive alignment. In Teaching for Quality Learning at University, 2nd ed.; SRHE and Open University Press: Berkshire, UK, 2004; pp. 11-33.

13. Huball, H.; Burt, H. An integrated approach to developing and implementing learning centred curricula. Intern. J. Acad. Dev. 2004, 1, 51-65. [CrossRef]

14. Malini Reddy, Y.; Andrade, H. A review of rubric use in higher education. Assess. Eval. High. Educ. 2010, 35, 435-448. [CrossRef]

15. Kolb, D.A. Experiential Learning: Experience as the Source of Learning and Development, 2nd ed.; Pearson Education Inc.: Upper Saddle River, NJ, USA, 2015.

16. Gibbs, G. Learning by Doing: A Guide to Teaching and Learning Methods; Oxford Polytechnic: Oxford, UK, 1988.

17. Yardley, S.; Teunissen, P.W.; Dornan, T. Experiential learning: Transforming theory into practice. Med. Teach. 2012, 34, 161-164. [CrossRef] [PubMed]

18. Rest, J.; Narvaez, D.; Bebeau, M.J.; Thoma, S.J. Postconventional Moral Thinking: A Neo-Kohlbergian Approach; Lawrence Erlbaum Associates: Mahwah, NJ, USA, 1999.

19. Thoma, S.J.; Bebeau, M.J.; Bolland, A. The role of moral judgment in context-Specific professional decision making. In Getting Involved: Global Citizenship Development and Sources of Moral Values; Sense Publishers: Amsterdam, The Netherlands, 2008; pp. 147-160.

20. Bebeau, M.J.; Thoma, S.J. "Intermediate" concepts and the connection to moral education. Educ. Psychol. Rev. 1999, 11, 343-360. [CrossRef]

21. Roche, C.; Thoma, S.J.; Grimes, T.; Radomski, M. Promoting peer debate in pursuit of moral reasoning competencies development: Spotlight on educational intervention design. Innov. Pharm. 2017, 8. [CrossRef]

22. Roche, C.; Thoma, S.J. Insights from the defining issues test on moral reasoning competencies Development in community pharmacists. Am. J. Pharm. Educ. 2017, 81. [CrossRef] 
23. Roche, C.; Thoma, S.; Wingfield, J. From workshop to E-Learning: Using technology-enhanced "Intermediate Concept Measures" as a framework for pharmacy ethics education and assessment. Pharmacy 2014, 2, 137-160. [CrossRef]

24. Hatton, N.; Smith, D. Reflection in teacher education: Towards definition and implementation. Teach. Teach. Educ. 1995, 11, 33-49. [CrossRef]

25. Moon, J. Reflection in Learning and Professional Development; Kogan: Lonfon, UK, 1999.

26. Schon, D.A. Educating the Reflective Practitioner: Towards a New Design for Teaching and Learning in the Professions; Jossey-Bass: San Fransisco, CA, USA, 1991.

27. Hew, K.F.; Cheung, W.S. Student facilitators' habits of mind and their influences on higher-level knowledge construction occurrences in online discussions: A case study. Innov. Educ. Teach. Int. 2011, 48, 275-285. [CrossRef]

28. Hrastinski, S. A theory of online learning as online participation. Comput. Educ. 2009, 52, 78-82. [CrossRef]

29. Palloff, R.M.; Pratt, K. Assessing the Online Learner: Resources and Strategies for Faculty; Jossey Bass: San Fransisco, CA, USA, 2009.

30. Sthapornnanon, N.; Sakulbumrungsil, R.; Theeraroungchaisri, A.; Watcharadamrongkun, S. Social constructivist learning environment in an online professional practice course. Am. J. Pharm. Educ. 2009, 73. [CrossRef] [PubMed]

31. National Forum for the Enhancement of Teaching and Learning in Higher Education. Assessment of/for/as Learning: Principles. Dublin, Ireland, 2016. Available online: https://www.teachingandlearning.ie/resourcehub/student-success/assessment-of-for-as-learning/\#!/Principles (accessed on 28 April 2018).

32. Amin, Z.; Boulet, J.R.; Cook, D.A.; Ellaway, R.; Fahal, A.; Kneebone, R.; Maley, M.; Ostergaard, D.; Ponnamperuma, G.; Wearn, A.; et al. Technology-enabled assessment of health professions education: Consensus statements from the Ottawa 2010 conference. Med. Teach. 2011, 33, 364-369. [CrossRef] [PubMed]

33. Norcini, J.; Anderson, B.; Bollela, V.; Burch, V.; Costa, M.J.; Duvivier, R.; Galbraith, R.; Hays, R.; Kent, A.; Perrott, V.; et al. Criteria for good assessment: Consensus statement and recommendations from the Ottawa 2010 Conference. Med. Teach. 2011, 33, 206-214. [CrossRef] [PubMed]

34. Schlaefli, A.; Rest, J.R.; Thoma, S.J. Does moral education improve moral judgment? A meta-analysis of intervention studies using the Defining Issues Test. Rev. Educ. Res. 1985, 55, 319-352. [CrossRef]

35. Penn, W.Y. Teaching ethics-A direct approach. J. Moral Educ. 1990, 19, 124-138. [CrossRef]

36. Garrison, R.G.; Arbaugh, J.B. Researching the community of inquiry framework: Review, issues, and future directions. Internet High. Educ. 2007, 10, 157-172. [CrossRef]

37. Carini, R.M.; Kuh, G.D.; Klein, S.P. Student engagement and student learning: Testing the linkages. Res. High. Educ. 2006, 47, 1-32. [CrossRef]

38. Zhao, C.M.; Kuh, G.D. Adding value: Learning communities and student engagement. Res. High. Educ. 2004, 45, 115-138. [CrossRef]

39. Price, M.; Handley, K.; Millar, J.; O’Donovan, B. Feedback: All that effort, but what is the effect? Assess Eval. High. Educ. 2010, 35, 277-289. [CrossRef]

40. Vai, M.; Sosulski, K. Essentials of Online Course Design: A Standards Based Guide; Routledge: New York, NY, USA, 2011.

41. Ellaway, R.; Coral, J.; Topps, D.; Topps, M. Exploring digital professionalism. Med. Teach. 2015, 37, 844-849. [CrossRef] [PubMed]

42. Kennedy, D.; Hyland, A.; Ryan, N. Implementing Bologna in Your Institution. Writing and Using Learning Outcomes: A Practical Guide. 2007. Available online: https://www.researchgate.net/publication/238495834_ Writing_and_Using_Learning_Outcomes_A_Practical_Guide (accessed on 28 April 2019).

43. Quality and Qualifications Ireland (QQI). Irish National Framework of Qualifications (NFQ). Dublin, Ireland, 2012. Available online: https://www.qqi.ie/Articles/Pages/National-Framework-of-Qualifications-\%28NFQ\% 29.aspx (accessed on 28 April 2019).

(C) 2019 by the authors. Licensee MDPI, Basel, Switzerland. This article is an open access article distributed under the terms and conditions of the Creative Commons Attribution (CC BY) license (http://creativecommons.org/licenses/by/4.0/). 